\title{
Hubungan Citra Tubuh dengan Status Gizi pada Siswi di SMA Negeri 9 Surabaya
}

\section{The Relationship between Body Image and Nutritional Status of Female Students in Senior High School 9 Surabaya}

\author{
Muhammad Dimas Bimantara*1, Merryana Adriani², Dewi Retno Suminar ${ }^{3}$
}

\begin{abstract}
ABSTRAK
Latar Belakang: Usia remaja merupakan masa peralihan dari masa kanak-kanak menuju masa dewasa. Pada usia ini akan terjadi perubahan bentuk tubuh yang dapat mempengaruhi persepsi remaja mengenai citra tubuh khususnya remaja putri. Hasil studi pendahuluan di SMA Negeri 9 Surabaya menunjukkan bahwa 7 dari 10 siswi merasa tidak puas dengan bentuk tubuhnya sehingga mereka melakukan upaya tertentu, seperti mengatur pola makan hingga berolahraga demi mendapatkan tubuh yang ideal.

Tujuan: Tujuan penelitian ini adalah untuk menganalisis apakah terdapat hubungan antara citra tubuh dengan status gizi pada siswi di SMA Negeri 9 Surabaya.

Metode: Penelitian menggunakan desain cross-sectional dilakukan pada 76 siswi kelas XI dan XII di SMA Negeri 9 Surabaya. Kriteria inklusi pada penelitian ini adalah siswi tidak sedang menjalani diet khusus. Teknik pengambilan sampel menggunakan proportional random sampling. Pengumpulan data penelitian dilakukan dengan metode wawancara menggunakan kuesioner citra tubuh (BSQ-34) dan pengukuran antropometri. Analisis data menggunakan uji korelasi spearman $(\alpha=0,05)$.

Hasil: Hasil penelitian yang telah dilakukan menunjukkan bahwa lebih dari separuh responden mempunyai citra tubuh yang positif $(74 \%)$ dan status gizi yang normal (71\%). Ada hubungan antara citra tubuh dengan status gizi pada siswi di SMA Negeri 9 Surabaya $(p<0,001)$.

Kesimpulan: Citra tubuh berhubungan dengan status gizi pada siswi di SMA Negeri 9 Surabaya. Siswi dengan citra tubuh positif maka cenderung memiliki status gizi normal.
\end{abstract}

Kata kunci: citra tubuh, siswi, status gizi

\section{ABSTRACT}

Background: Teenage age is a period of transition from childhood to adulthood. At this age there will be changes in body shape that can affect teenagers' perceptions of body image, especially adolescent girl. The result of a preliminary study at Senior High School 9 Surabaya showed that 7 out of 10 female students were dissatisfied with their body shape so they made certain efforts, such as managing their diet to exercise for get an ideal body.

Objective: The purpose of this study was to analyze whether there was a relationship between body image and nutritional status in female students at Senior High School 9 Surabaya.

Methods: The study used a cross-sectional design carried out 76 of 11th and 12th grades in Senior High School 9 Surabaya. The inclusion criteria in this study were the students not undergoing special diet. The sampling technique used was proportional random sampling. Research data collection was conducted by interview method using body image questionnaire (BSQ-34) and anthropometric measurements. Data analysis used spearman correlation test ( $\alpha=0.05)$.

Results: The results of this study showed that more than half of the respondents have a positive body image (74\%) and normal nutritional status (71\%). There was significant relationship between body image and nutritional status of female students at Senior High School 9 Surabaya $(p<0.001)$.

Conclusion: Female nutritional status is influenced by body image. Students with a positive body image tend to have normal nutritional status.

Keywords: body image, female students, nutritional status 


\author{
*Koresponden: \\ mdmsbimantara@gmail.com \\ 1,2Departemen Gizi Kesehatan, Fakultas Kesehatan Masyarakat, Universitas Airlangga \\ Kampus C Mulyorejo, 60115, Surabaya, Jawa Timur, Indonesia \\ ${ }^{3}$ Fakultas Psikologi, Universitas Airlangga \\ Kampus B Jl. Airlangga 4-6, 60286, Surabaya, Jawa Timur, Indonesia
}

\section{PENDAHULUAN}

Usia remaja merupakan usia peralihan dari masa kanak-kanak menuju masa dewasa dengan rentang usia antara 10-19 tahun (WHO). ${ }^{1}$ Pada usia ini terjadi perubahan dan perkembangan antara lain perubahan bentuk tubuh, kapasitas reproduksi, dan psikologis. Pada usia ini pula timbul ketertarikan yang tinggi pada lawan jenis, khususnya remaja putri akan memperhatikan bentuk tubuh dan berusaha menjadi semenarik mungkin. Banyak upaya yang dilakukan remaja putri untuk menunjang penampilan salah satunya yaitu, mengurangi berat badan dengan cara membatasi atau mengurangi frekuensi dan jumlah makan, bahkan memuntahkan makanan yang telah dimakan. ${ }^{2}$

Pada tingkat Sekolah Menengah Pertama (SMP) usia 13-15 tahun prevalensi remaja kurus sebesar $11,1 \%$ dan remaja gemuk sebesar 10,8\%, sedangkan pada timgkat Sekolah Menengah Atas (SMA) usia $\leq 16-18$ tahun prevalensi remaja kurus sebesar $9,4 \%$ dan remaja gemuk sebesar $7,3 \% .^{3}$ Masalah tersebut disebabkan pandangan remaja putri terhadap bentuk tubuhnya. Pandangan yang salah dapat menimbulkan persepsi negatif terhadap citra tubuh.

Citra tubuh atau biasa disebut dengan body image merupakan keyakinan atau persepsi individu yang dengan sadar mengenai bentuk tubuhnya. Citra tubuh dikategorikan menjadi dua yaitu citra tubuh positif dan citra tubuh negatif. Dikatakan citra tubuh positif adalah pandangan positif seseorang terhadap tubuhnya dan menerima bentuk tubuh yang dimiliki, sementara itu citra tubuh negatif adalah pandangan negatif seseorang terhadap bentuk tubuh dan tidak puas dengan bentuk tubuh yang dimiliki. ${ }^{4}$ Dampak dari pandangan negatif terhadap bentuk tubuh diri sendiri berkaitan dengan kesehatan mental, emosional, dan perilaku, seperti gangguan pola makan dengan diet yang tidak sehat dan porsi berlebih, depresi, dan tidak percaya diri. Pada umumnya remaja putri beranggapan bahwa bentuk tubuh yang ideal adalah tubuh yang langsing dan tinggi. Persepsi negatif mengenai citra tubuh dapat mempengaruhi pola makan sehingga akan mempengaruhi status gizi remaja putri. ${ }^{5}$

Berdasarkan hasil penelitian sebelumnya, untuk mendapatkan tubuh yang lebih menarik didapatkan bahwa 6 dari 11 siswi SMA Negeri 9 Manado yang merasa kurang puas dengan bentuk tubuhnya kemudian melakukan pengaturan pola makan dengan membatasi asupan gula, minuman bersoda, daging dan karbohidrat. ${ }^{6}$ Masalah gizi dapat berupa kondisi gizi berlebih atau kurang. Terdapat pula penelitian lain yang menyebutkan bahwa risiko terjadinya gizi berlebih pada remaja putri yang tidak puas dengan ukuran tubuhnya 7,2 kali lebih tinggi dari pada yang merasa puas. ${ }^{7}$
Sementara itu, hasil studi pendahuluan pada penelitian ini menunjukkan bahwa 7 dari 10 siswi merasa tidak puas dengan bentuk tubuhnya. Hasil pendahuluan tersebut sejalan dengan hasil penelitian dari Kurniawan et al., yang menyatakan bahwa sebanyak $78,6 \%$ remaja putri dari 100 remaja memiliki pandangan negatif terhadap penampilannya. Hal tersebut mendorong siswi yang bersangkutan untuk melakukan upaya-upaya tertentu untuk membentuk tubuh, misalnya dengan mengatur pola makan hingga berolahraga. Berdasarkan penjelasan diatas maka penting untuk melakukan penelitian terkait dengan status gizi remaja putri. Penelitian ini memiliki tujuan untuk menganalisis hubungan antara citra tubuh dengan status gizi pada siswi di SMA Negeri 9 Surabaya.

\section{METODE}

Penelitian ini menggunakan desain crosssectional. Lokasi penelitian adalah di SMA Negeri 9 Surabaya. Berdasarkan hasil penelitian sebelumnya yang melakukan pengukuran status gizi pada siswa SMA Negeri 5 Surabaya mulai dari kelas X-XII dengan rentang usia 15-18 tahun didapatkan presentase siswa dengan status gizi overweight sebesar $33,1 \%$ dan obesitas $8,9 \% .{ }^{8}$ Prevalensi tersebut lebih tinggi dibandingkan angka prevalensi nasional pada data Riskesdas tahun 2014. Pengambilan data dilakukan pada bulan September 2018. Kriteria inklusi pada penelitian ini adalah tidak sedang menjalani diet khusus. Sampel dihitung menggunakan rumus Lwanga dan Lemeshow (1991) sehingga didapatkan 76 siswi dari total populasi 398 siswi kelas 11 dan 12 . Teknik penentuan sampel menggunakan proportional random sampling pada tiap kelas 11 dan 12 .

Variabel bebas yang diteliti adalah citra tubuh, sedangkan variabel terikat yang digunakan adalah status gizi. Teknik pengumpulan data dengan wawancara menggunakan Body Shape Questionnaire (BSQ). BSQ adalah salah satu alat yang digunakan untuk menilai citra tubuh untuk mengukur kekhawatiran tentang berat badan dan bentuk tubuh individu. BSQ terdiri dari 34 pertanyaan yang terkait dengan penampilan dan bentuk tubuh seseorang selama 4 minggu terakhir. Reliabilitas dan validitas kuesioner BSQ telah dilakukan di Indonesia. Kuesioner tersebut menggunakan skala Likert yang diinterpretasikan dalam 2 kategori, antara lain body image positif (skor < 110) dan body image negatif (skor $\geq$ 110). ${ }^{9}$ Penilaian variabel terikat atau status gizi menggunakan Indeks Massa Tubuh (IMT). Pengukuran tinggi badan menggunakan microtoise dengan tingkat ketelitian $0,1 \mathrm{~cm}$ dan pengukuran berat badan menggunakan timbangan digital untuk mengetahui status gizi remaja putri dengan tingkat ketelitian $0,1 \mathrm{~kg}$. 
Berdasarkan Kemenkes (2013), indikator tersebut, yaitu Z-skor $\geq-3 \mathrm{~s} / \mathrm{d}<-2$ : kurus; Z-skor $\geq-2 \mathrm{~s} / \mathrm{d}$ $\leq 1$ : normal; Z-skor $>1 \mathrm{~s} / \mathrm{d} \leq 2$ : gemuk; dan Z-skor $>2$ : obesitas. Analisis data menggunakan software SPSS uji Spearman dengan $\alpha=0,05$ untuk mencari tahu ada atau tidaknya hubungan antara citra tubuh dengan status gizi.

Penelitian ini telah mendapat persetujuan layak etik dari Komisi Etik Fakultas Kesehatan Masyarakat Universitas Airlangga dengan nomor 483-KEPK tanggal 9 Agustus 2018. Setiap responden telah menyetujui ikut serta dalam penelitian ini menandatangani informed consent.

\section{HASIL DAN PEMBAHASAN}

Berdasarkan Tabel 1 menunjukkan bahwa sebanyak $48 \%$ responden berusia 17 tahun. Tingkat pengetahuan gizi responden sebagian besar memiliki pengetahuan yang cukup yaitu $83 \%$. Hasil tersebut tidak mempengaruhi hasil penelitian karena peneliti hanya melihat distribusi data tingkat pengetahuan gizi responden. Namun terdapat beberapa penelitian sebelumnya yang menunjukkan adanya hubungan antara pengetahuan gizi dengan status gizi. Semakin baik pengetahuan gizi maka mempengaruhi remaja putri dalam peningkatan status gizi. ${ }^{10}$

Citra tubuh merupakan hal yang sangat penting bagi remaja khususnya remaja putri. Remaja putri cenderung memperhatikan penampilan fisik. Penampilan fisik yang tidak sesuai dengan apa yang diharapkan dapat menyebabkan ketidakpuasan terhadap bentuk tubuhnya. Rasa tidak puas terhadap bentuk tubuhnya dapat menyebabkan remaja putri memiliki persepsi diri yang menyimpang. Pada kategori citra tubuh diketahui bahwa sebanyak $73 \%$ responden memiliki citra tubuh positif, hal tersebut diketahui berdasarkan hasil wawancara menggunakan kuesioner citra tubuh (BSQ34).

Tabel 1. Distribusi Karakteristik pada Siswi di SMA Negeri 9 Surabaya

\begin{tabular}{lcc}
\hline \multicolumn{1}{c}{ Kategori } & $\mathbf{n}$ & (\%) \\
\hline Usia & & \\
15 tahun & 6 & 8 \\
16 tahun & 31 & 41 \\
17 tahun & 37 & 49 \\
18 tahun & 2 & 2 \\
\hline Tingkat Pengetahuan & & \\
Gizi & & \\
Kurang (<60\%) & 0 & 0 \\
Cukup (60-80\%) & 63 & 83 \\
Baik (>80\%) & 13 & 17 \\
\hline Citra Tubuh & & \\
Positif & 56 & 74 \\
$\quad$ Negatif & 20 & 26 \\
\hline Status Gizi & & \\
$\quad$ Kurus & 6 & 8 \\
$\quad$ Norma & 52 & 71 \\
$\quad$ Gemuk & 12 & 16 \\
$\quad$ Obesitas & 4 & 5 \\
\hline
\end{tabular}

Hasil tersebut sejalan dengan penelitian sebelumnya pada remaja putri usia 15-18 tahun yang menunjukkan bahwa lebih dari setengah responden penelitian memiliki citra tubuh yang positif dengan persentase $80,6 \%$. Seseorang dengan citra tubuh positif akan merasa puas akan tubuhnya baik itu ukuran tubuh, dan bentuk tubuh pada bagian tertentu ataupun keseluruhan, sedangkan orang dengan citra tubuh negatif tidak puas dengan tubuhnya. Citra tubuh negatif biasanya bertahan dalam jangka waktu yang lama. Sering sekali remaja putri merasa terlalu gemuk ataupun terlalu kurus dari ukuran yang sebenarnya, sehingga mereka ingin mengubah bentuk tubuhnya dengan cara diet ataupun olah raga yang berlebihan. Persepsi mengenai citra tubuh pada remaja putri dapat mengakibatkan implikasi negatif bagi kesejahteraan fisik dan psikologisnya. ${ }^{11}$ Namun, terkadang remaja putri melakukan diet ketat, mengkonsumsi pil pelangsing, atau berolahraga demi mencapat postur tubuh yang diinginkan tanpa memperhatikan keamanan dari hal-hal yang mereka lakukan. ${ }^{12}$

Hal tersebut kemudian bisa berpengaruh terhadap perilaku makan remaja putri tersebut. Pola konsumsi yang tidak seimbang dapat mengakibatkan tidak sesuainya pasokan energi dengan keluarnya energi dalam menjalani aktifitas sehari-hari. ${ }^{13} \mathrm{Hal}$ tersebut dapat berdampak pada status gizi remaja.

Pada kategori status gizi diketahui bahwa remaja putri dengan status gizi normal memiliki persentase sebesar $71 \%$. Sama halnya dengan penelitian sebelumnya pada remaja putri yang menunjukkan bahwa lebih dari setengah responden dalam penelitian ini memiliki status gizi yang normal yaitu sebesar $77,78 \%{ }^{14}$ Penelitian tersebut juga sejalan dengan penelitian lainnya yang dilakukan pada remaja putri usia 15-18 tahun dan menjelaskan bahwa lebih dari separuh responden memiliki status gizi normal dengan persentase sebesar $72 \%$.

Status gizi merupakan keadaan tubuh yang disebabkan oleh keseimbangan antara asupan zat gizi dengan kebutuhan tubuh. Status gizi bisa dipengaruhi dengan konsumsi pangan dan akitivitas fisik dari seseorang. ${ }^{15}$ Untuk menghasilkan status gizi yang baik maka dapat diimbangi dengan asupan protein dan energi yang masuk dan keluar dengan seimbang. ${ }^{16}$ Sehingga, status gizi baik akan terjadi apabila tubuh digunakan dengan efisien. Semakin normal status gizi maka seseorang cenderung memiliki citra tubuh yang positif.

Berdasarkan Tabel 2 uji korelasi menggunakan uji spearman menyatakan bahwa antara citra tubuh dengan status gizi menunjukkan hubungan yang signifikan dengan nilai $p<0,001$. Hasil tersebut menunjukkan adanya hubungan antara citra tubuh dengan status gizi pada siswi di SMA Negeri 9 Surabaya. Hasil dari penelitian sejalan dengan penelitian lainnya yang dilakukan pada remaja putri usia 15-18 tahun yang menerangkan jika citra tubuh dan status gizi remaja putri memiliki hubungan yang signifikan. Hasil penelitian lain yang dilakukan pada mahasiswi tingkat I jurusan gizi Poltekkes Kemenkes Padang Tahun 2014 juga terlihat jika citra tubuh dengan status gizi memiliki hubungan yang signifikan. ${ }^{17}$

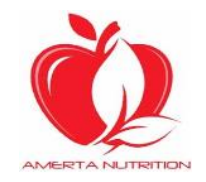

(C)2019. Bimantara, et al. Open access under CC BY - SA license.

Received: 17-01-2019, Accepted: 18-02-2019, Published online: 01-6-2019.

doi: 10.20473/amnt.v3.i2.2019.85-88, Joinly Published by IAGIKMI \& Universitas Airlangga 
Tabel 2. Uji Korelasi dengan Status Gizi

\begin{tabular}{|c|c|c|c|c|c|c|c|c|c|c|c|c|}
\hline \multirow{2}{*}{ Citra Tubuh } & \multicolumn{2}{|c|}{ Kurus } & \multicolumn{2}{|c|}{ Normal } & \multicolumn{2}{|c|}{ Gemuk } & \multicolumn{2}{|c|}{ Obesitas } & \multicolumn{2}{|c|}{ Total } & \multirow[t]{2}{*}{$p$ value } & \multirow[t]{2}{*}{$r$} \\
\hline & $\mathbf{n}$ & $\%$ & $n$ & $\%$ & $n$ & $\%$ & $\mathrm{n}$ & $\%$ & $n$ & $\%$ & & \\
\hline Positif & 6 & 11 & 46 & 82 & 2 & 4 & 2 & 4 & 56 & 100 & \multirow{3}{*}{$<0,001$} & \multirow{3}{*}{0,533} \\
\hline Negatif & 0 & 0 & 8 & 40 & 10 & 50 & 2 & 10 & 20 & 100 & & \\
\hline Total & 6 & 8 & 54 & 71 & 12 & 16 & 4 & 5 & 76 & 100 & & \\
\hline
\end{tabular}

Penampilan fisik merupakan modal penting bagi setiap orang, khususnya bagi remaja putri. Hasil penelitian pada siswi kelas 11 dan kelas 12 SMA 9 Surabaya menunjukkan bahwa hanya terdapat beberapa dari mereka yang tidak puas dengan bentuk tubuhnya. Terdapat 12 siswi yang memiliki tubuh gemuk dan 4 siswi yang mengalami obesitas. Sebenarnya, masalah ketidakpuasan terhadap bentuk tubuh dapat membuat seorang remaja putri memiliki pikiran yang negatif dan berdampak pada status gizi yang tidak normal. Sehingga, seharusnya remaja putri selalu memiliki pikiran yang positif terhadap bentuk tubuh yang dimilikinya.

\section{KESIMPULAN}

Citra tubuh berhubungan dengan status gizi pada siswi di SMA Negeri 9 Surabaya. Berdasarkan uji spearman menyatakan bahwa antara citra tubuh dengan status gizi menunjukkan hubungan yang signifikan dengan nilai $p<0,001$. Hasil tersebut menunjukkan adanya hubungan antara citra tubuh dengan status gizi pada siswi di SMA Negeri 9 Surabaya. Remaja khususnya remaja putri perlu untuk diarahkan pada status gizi normal agar memiliki citra tubuh positif.

\section{ACKNOWLEDGEMENT}

Ucapan terimakasih peneliti sampaikan kepada seluruh responden penelitian, seluruh guru dan staff di SMA Negeri 9 Surabaya, serta teman-teman yang telah membantu kelancaran penelitian ini.

\section{REFERENSI}

1. Pusat Data dan Informasi Kementerian Kesehatan RI. Situasi Kesehatan Reproduksi Remaja. (2015).

2. Nomate, E. S., Nur, M.L., \& Toy, S. M. Teman Sebaya, Citra Tubuh, Pola Konsumsi, dan Status Gizi Remaja Putri. Unnes J. Public Heal. 6, 1-4 (2017).

3. Badan Penelitian dan Pengembangan Kesehatan. Riset Kesehatan Dasar (RISKESDAS) 2013. Lap. Nas. 2013 1-384 (2013).

4. Willianto, D. A. Hubungan Antara Konsep Diri dan Citra Tubuh pada Perempuan Dewasa Awal. (2017).

5. Amar, M., I., Puspita, I. D., Nanang, N. Implementasi Program Bimbingan Persepsi Positive Body Image Terhadap Pengetahuan Gizi Remaja dan Status Gizi Remaja Putri. Public Heal.
Sci. J. 10, 1-11 (2018).

6. Lintang, A., Ismanto, Y., \& Onibala, F. Hubungan Citra Tubuh dengan Perilaku Diet pada Remaja Putri di SMA Negeri 9 Manado. eJournal Keperawatan 3, 1-8 (2015).

7. Ristianti, A. Hubungan Antara Dukungan Sosial Teman Sebaya dengan Identitas Diri Pada Remaja di SMA Pusaka 1 Jakarta. eJournal Psikol. 1-28 (2012).

8. Putra, W. N. Hubungan Pola Makan, Aktifitas Fisik, dan Aktifitas Sedentari dengan Overweight di SMA Negeri 5 Surabaya. J. Berk. Epidemiol. 5, 298-310 (2017).

9. Yushinta, A. N. \& \& Adriyanto. Hubungan Antara Perilaku Makan dan Citra Tubuh dengan Status Gizi Remaja Putri Usia 15-18 Tahun. Amerta Nutr. 2, 147-154 (2018).

10. Florence, A.G. Hubungan Pengetahuan Gizi Dengan Status Gizi Pada Mahasiswa TPB Sekolah Bisnis Dan Manajemen Institut Teknologi Bandung. (2017).

11. Kerner, C., Haerens, L. \& Kirk, D. Understanding Body Image in Physical Education: Current Knowledge And Future Directions. Eur. Phys. Educ. Rev. 24, 255-265 (2018).

12. Veldhuis, J., Poel, F., Pepping, R., Konijn, E. A. \& Spekman, M. L. C. Skinny is prettier and normal : I want to be normal ": Body image of nonWestern ethnic minority children in the Netherlands. "Skinny is prettier and normal : I want to be normal "- Perceived body image of non-Western ethnic minority children in the $\mathrm{Ne}$. Body Image 20, 74-86 (2017).

13. Miko, A. \& \& Dina, P. B. Hubungan Pola Makan Pagi dengan Status Gizi pada Mahasiswi Poltekkes Kemenkes Aceh. Aceh Nutr. J. 1, 83-87 (2016).

14. Damayanti, A. E. Hubungan Citra Tubuh, Aktivitas Fisik, dan Pengetahuan Gizi Seimbang dengan Status Gizi Remaja Putri. (2016).

15. Karim, M. A. Hubungan Asupan Makanan, Aktivitas Fisik dengan Status Gizi Peserta Didik Kelas VII SMP Negeri 5 Sleman. (2017).

16. Restuastuti, T., Jihadi, M. Ernalia, Y. Hubungan Pola Makan dan Aktivitas Fisik Terhadap Obesitas Pada Remaja Di SMA Negeri 5 Pekanbaru. Jom FK 3, 1-20 (2016).

17. Putri, G. P. Hubungan Citra Tubuh (Body Image) dan Pola Konsumsi dengan Status Gizi Mahasiswi Tingkat I Jurusan Gizi Poltekkes Kemenkes Padang Tahun 2014. Scientif Paper (2014). 